5

\title{
LA DIMENSIÓN POLÍTICA DE LOS DISCURSOS SOCIALES
}

Ximena Triquell

Santiago Ruiz

xtriquell@gmail.com / Licenciada en Letras (Universidad Nacional de Córdoba), Magister y Doctora en Teoría Crítica (Universidad de Nottingham, Inglaterra). Docente del Departamento de Cine y TV, Facultad de Artes, Universidad Nacional de Córdoba.

sgoruiz@gmail.com/Profesor en Letras Modernas y Magister en Sociosemiótica (Universidad Nacional de Córdoba). Docente de Escuela de Ciencias de la Información, Universidad Nacional de Córdoba. 


\section{RESUMEN}

El presente trabajo parte de la necesidad de elaborar una definición de «política», o más bien de «lo político», que no refiriera exclusivamente a los efectos del discurso (el poder), tal como podría desprenderse de cierta lectura de la Semiosis Social (Verón, 1987). Para ello, siguiendo la diferencia que establece Verón entre definiciones descriptivas y analíticas de la ideología/ «lo ideológico» y del poder, recurrimos a la distinción entre «la política», como término descriptivo, y «lo político», como instancia analítica. En el primer caso, el término referiría a la estructura (en las democracias representativas, en general partidaria) a través de la cual se disputa el poder político (también en términos descriptivos, esto es, como poder institucional), a través de una «ideología» (nuevamente, en términos descriptivos, esto es de determinada gramática de producción). Por su parte, como categoría de análisis, «lo político» permite referir a una manera de representar las relaciones que sostienen la estructura social (en nuestro caso entendida en términos de semiosis). Esta distinción, ya postulada desde otras teorizaciones, posee una dimensión semiótica que merece ser explorada. Ese es el propósito de este artículo.

\section{PALABRAS CLAVE}

$>$ discurso

$>$ política del discurso

$>$ «lo político»

$>$ discurso político

$>$ semiosis social 
ABSTRACT

This article originates in the need for a definition of «politics», or rather «the political», that is not referred exclusively to the effects (the power) of discourses, as it could be assume in a certain reading of the Social Semiosis (Verón, 1987). Following Verón distinction between descriptive and analytical definitions of ideology / «the ideological» and of power, we establish a distinction between «politics», as a descriptive term, and «the political», as an analytical instance. In the first case, the term would refer to the structure (in representative democracies, organized through political parties) which disputes political power (also in descriptive terms, that is, as institutional power), through an «ideology» (again, in descriptive terms, i.e. a certain grammar for production). As a category of analysis, «the political» refers to a way of representing the relationships that sustain the social structure (in our case understood in terms of semiosis). This distinction, already proposed by other theorizations, possesses a semiotic dimension that deserves to be explored. That is the purpose of this article.

\section{KEY WORDS}

$>$ discourse

$>$ discourse politics

$>$ «the political»

$>$ political discourse

$>$ socialsemiosis 